\title{
Review and Analysis of Current Responses to COVID-19 in Brazil and India: Period of January to July 2020
}

\author{
Raden Mas Try Anant Djoko Wicaksono ${ }^{1 *}$ \\ ${ }^{1}$ Departement of Law, Gadjah Mada University, and Departement of Public Policy, \\ School of Government E' Public Policy (SGPP) - Indonesia \\ *Corespending author: ${ }^{1 *}$ tryananto.wicaksono@gmail.com
}

\begin{abstract}
The COVID-19 pandemic is impacting emerging markets through an unprecedented mix of domestic and external shocks whose combined effects are very hard to predict. Through this analysis, the author would explore more regarding the government policy priorities in dealing with COVID-19 especially from the emerging countries. Brazil and India as the best countries to be weighed with Indonesia due to some similarities they have. The research method used in this research is a descriptive qualitative and comparative study, the types of comparable, in this case, are Most Different System Designs (MDSD). The results show that Brazil has a partial-lockdown system and India has a full-lockdown system, yet in both countries, there is a high number of death rates and confirmed cases. The politics of the moment are only a piece of the policy environment, however, economics as of a major factor. Thus, the paper suggests ensuring that the lockdown is not being lifted prematurely; it is crucial to significantly ramp up the capacity of the healthcare system.
\end{abstract}

Keywords: Emerging Countries; Government policy; Comparative Study, COVID-19 Pandemic.

\section{Introduction}

On 31 December 2019, the World Health Organization (WHO) China Country Office was informed of cases of pneumonia of unknown etiologic 
(unknown cause) detected in Wuhan City, Hubei Province of China. On 5 January 2020, WHO published the first Disease Outbreak News on the new virus. On March 11, 2020, WHO declared the new virus known as Coronavirus (COVID-19) a pandemic, pointing to the over 118,000 cases of the coronavirus illness in over 110 countries and territories around the world and the sustained risk of further global spread especially for business activities. ${ }^{1}$

Brazil has become the second country, after the US, to register more than 50,000 deaths from Covid-19 in worldwide. ${ }^{2}$ The coronavirus has caused an economic downfall for the whole world including Brazil, and the government has introduced series policies to salvage another wave of the ongoing economic crisis. Brazil's economy was already fragile before the pandemic. In 2019, it grew 1.1 percent, its weakest growth in three years. ${ }^{3}$ The first-quarter of 2020, Gross Domestic Product (GDP) falls 1.5 percent. $^{4}$

On the other hand, India reported with over 18,500 new coronavirus cases, pushing the country's total above 566,000 on June 2020. The Prime Minister Narendra Modi has imposed a nationwide lockdown, ordering its 1.3 billion people to stay home with nearly all services and factories suspended. ${ }^{5}$ According to the National Sample Survey Office's (NSSO) for the year 2017-18 show that India's joblessness was 6.1 per cent of the labour force, which is amongst the highest since $1972-73 .{ }^{6}$ In 2020 , the projections will be much more worsening.

The COVID-19 pandemic is impacting emerging markets through an unprecedented mix of domestic and external shocks whose combined effects are very hard to predict. Among these, emerging markets are confronting a sharp tightening in global financial conditions. According to the latest International Monetary Fund (IMF) projections suggest emerging markets will contract by

1 Ducharme, J. World Health Organization Declares COVID-19 a 'Pandemic.' Here's What That Means. 11 March 2020. https://time.com/5791661/who-coronavirus-pandemic-declaration/ (August 19, 2020).

2 BBC News. oronavirus: Brazil becomes second country to pass 50,000 deaths. 22 June 2020. https:// www.bbc.com/news/world- latin-america-53132225 (August 19, 2020).

3 CGTN. COVID-19 Global Roundup: Brazil facing 'crisis moment. 2020. https://news.cgtn. com/news/2020-06-20/COVID-19-Global- Roundup-Brazil-facing-crisis-moment--RtEYfn1C4E/index.html (August 19, 2020).

4 Schipani, Andres. Brazil's first-quarter GDP falls 1.5\% as Covid-19 cases climb. 2020. https://www. ft.com/content/d0461a1f- 84be-4704-91f6-da02d792a810 (August 19, 2020).

5 Yiwei, Hu. Graphics: How COVID-19 lockdown hit India's economy. 2020. https://news. cgtn.com/news/2020-06-30/Graphics-How-COVID-19-lockdown-hit-India-s-economyRJSmm5Laes/index.html (August 19, 2020).

6 Malhan, Meera, Navneet Manchanda, dan Aryaman Bhatia. Lessons from India's jobless growth story. 2019. https://www.thestatesman.com/opinion/lessons-indias-jobless-growth-story-1502835431.html (August 19, 2020). 
1 percent this year. This looks far better than the 6 percent decline predicted in richer countries. ${ }^{7}$

More than a decade after the global financial crisis, the world is struggling with the health and economic effects of a profound new crisis caused by the COVID-19 pandemic. The pandemic will severely impact growth across all regions, especially for emerging market such Brazil and Indonesia that growth projectios is under 0 percent similar with developd countries such as United States and Japan. While India projections is above 1 percent along with China (see Table 1).

Table 1. World Economic Outlook Growth Projections (real GDP, annual percent change)

\begin{tabular}{llll}
\hline & 2019 & 2020 & 2021 \\
\hline Brazil & 1.1 & -5.3 & 2.9 \\
\hline China & 6.1 & 1.0 & 8.2 \\
\hline India & 4.2 & 1.9 & 7.4 \\
\hline Indonesia & & -0.3 & \\
\hline Japan & 0.7 & -5.8 & 2.4 \\
\hline United States & 2.3 & -8.0 & 4.5 \\
\hline & \multicolumn{2}{l}{ Source: IMF, 2020 }
\end{tabular}

According to Jack A. on "Rise of the TIMBIs: Turkey, India, Mexico, Brazil and Indonesia", Turkey, India, Mexico, Brazil and Indonesia share favorable demographics and democracy and are already large economies. Their GDPs combined have already surpassed that of China and will be much faster growing in the coming decades. Their combination of booming labor forces and political openness points to rapid increases in human capital and innovation that will propel these regional powers into global powers in the near future. ${ }^{9}$

Through this analysis, the author would explore more regarding the government policy priorities in dealing with COVID-19 especially from the emerging countries. Whether political interest, economic priority, social-cultural

\footnotetext{
7 IMF. World Economic Outlook. June 2020. https://www.imf.org/en/Publications/WEO/Issues/2020/0 6/24/WEOUpdateJune2020 (August 19, 2020)

8 Ibid.

9 Goldstone, Jack A. Rise of the TIMBIs: Turkey, India, Mexico, Brazil and Indonesia. Washington, D.C: Brookings Institution, 2011.
} 
or the administrative environment. Thus, for a comparative study purpose, Brazil and India as the best countries to be weighed with Indonesia due to some similarities they have, as the following:

(1) Population Number. Half the world's population was concentrated in just six countries, namely China, India, United States, Indonesia, Brazil, Pakistan and Nigeria. India as the second largest population in the world, with over 1.35 billion. Indonesia 267.7 million and Brazil 209.5 million; ${ }^{10}(2)$ Emerging Markets. According to $\mathrm{PwC}$ project GDP to 2050 for 32 of the largest economies in the world including Brazil, India and Indonesia, which together currently account for around 85\% of global GDP. with the E7 economies of Brazil, China, India, Indonesia, Mexico, Russia and Turkey growing at an annual average rate of almost $3.5 \%$ over the next 34 years, compared to just $1.6 \%$ for the advanced G7 nations of Canada, France, Germany, Italy, Japan, the UK and the US;11 (3) G20 Member. Brazil has emerged as a regional leader in South America that represent in G20. India boasts the largest emerging economy in the G20 after china. Indonesia, the only countries that member of G20 from Southeast Asia; ${ }^{12}$ (4) Geographically, Brazil dominates South America; it shares a border with every country on the continent except Chile and Ecuador. India occupies the majority of the South Asian landmass and has a land or maritime boundary with every state in the region. Indonesia straddles two oceans and has maritime boundaries with most Southeast Asian nations, as well as Australia and India; (5) Democracy. Brazil recent success at reducing inequality while boosting economic growth, democracy, racial diversity and capacity to mediate international disputes. India has endured with only a single brief interruption since independence. Indonesian as newly consolidated democracy and status as the world's most populous Muslim-majority nation. ${ }^{13}$

10 Hackett, Conrad. Which 7 countries hold half the world's population? 2020. https://www.pewresearch. org/fact-tank/2018/07/11/world-population-day/\#: :text $=$ China $\% 20$ has $\% 20$ the $\% 20$ world's $\% 20$ largest,have \% 20fewer\%20people\%20than\%20India (August 19, 2020).

11 PwC. The Long View How will the global economic order change by 2050. Summary Report, London: PricewaterhouseCoopers LLP, 2017.

12 Kliman, Daniel M., dan Richard Fontaine. Global Swing States Brazil, India, Indonesia, Turkey and the Future of International Order. Washington D.C .: Center for a New American Security, 2012.

13 Kliman. 


\section{Literature Review}

According to Riant Nugroho, policy is an authoritative decision. Decision made by the one holds the authority, formal and informal. While public are a sphere where people become citizen, a space where citizens interact, where state and society exist. Thus, public policy means any state of or Government (as the hold of the authority) decision to manage public life (as the sphere) in order to reach the motion of the nation (remember, nation is consisting of two institutions: state and society). ${ }^{14}$

Not every issue can be the government top priority. Additionally, the priorities of government can change rapidly and dramatically with focusing events. Focusing events are significant episodes or experiences that catapult particular issues to prominence on the public agenda looking for focusing events can help us understand movements on public policy issues. ${ }^{15}$

With a realization of competing priorities and focusing events, we discuss four factors that affect the context of policymaking: (1) The political environment: the priorities of political parties and elected officials do much to shape the policymaking agenda. For example, at the start of Donald Trump's administration in 2017, a stated policy priority was to repeal the Affordable Care Act, better known as Obamacare; ${ }^{16}$

(2) The economic environment: The politics of the moment are only a piece of the policy environment, however, as economics is also a major. Money plays a large role in many situations. When the economy is not performing well, a nation will elect leaders are often focused on "fixing" the economy. On the flipside, when the economy is performing well, the nation is willing to engage in other policy issues that may be construed as being more "quality of life."; (3) The social and cultural environment: The norms of a society and what is culturally acceptable drive policymaking. Who we are as a country helps set the boundaries of what types of policies are likely to be enacted and successfully implemented. For instance, scientists and engineers in the next year determine that in order to protect the planet from carbon emissions the most efficient and effective course of action would be for countries to drive eco-friendly (Kraft \& Furlong, 2019, p.22);

\footnotetext{
14 Nugroho, Riant. Public Policy. Jakarta: PT Elex Media Komputindo, 2009.

15 Kraft, Michael E., dan Scott R. Furlong. Defining U.S. Public Policy Making. California: SAGE Publications, Inc., 2019.

16 Kraft, 21.
} 
(4) The administrative environment. The administrative environment concerns that in government (or the broader public sector, for that matter) will implement the policy. Although these seemingly less important details are not as pervasive in public debate about a particular policy issue, they are extremely significant as policy ideas are being offered to solve a public problem. Sometimes the debate is less about government doing something and more about what level of government should do about something (Kraft \& Furlong, 2019, p.23); (5) The theory is helpful because they account for all the different ways public problems are approached and understood. ${ }^{17}$

Several research has explains the policy applied by Brazil and India. First, The paper, "Novel Coronavirus (COVID-19) in India: Current Scenario" explains about the review briefly covers the introduction, possible mode of transmission, definitions, some basic advices, diagnosis, treatment and management protocol being followed right now in India by Varsha Kachroo from Dept. of Medicine, Govt. Medical College, Jammu; however subjected to change in due course of time as is the number of cases and mortality. The health care personnel are doing their job perfectly and so is the Government, but the paper result most important for everyone being a citizen of India is to maintain social distancing and follow advisories strictly. ${ }^{18}$

Another research explains the India policy, written by M. David., et. al., entitled "COVID-19 (Coronavirus): A Global Emergency Outbreak and Its Implications in India" discuss on the implications of Covid-19 in Indian scenario along with report on active cases, death toll, cured cases, and strategies employed for the pandemic control. The result shows Indian government is taking lots of efforts to control the transmission of the virus that spreads rapidly among humans. Strategies such as self-quarantine, social distancing and 40-days countrywide lockdown helped to slow down the virus, which could have spread tremendously otherwise. ${ }^{19}$

However, it is different from two researches above that focused on India's policy. The paper, "COVID-19 in Brazil: So what?" shows Brazil difficult time to combat COVID-19. The result The Indigenous population has been under

17 Sabatier, Paul. Theories of the Policy Process. New York: Routledge, 2007.

18 Kachroo, Varsha. "Novel Coronavirus (COVID-19) in India: Current Scenario." International Journal of Research and Review 7, no. 3 (2020): 435-447.

19 David, M., Lokeshkumar, dan Suraj S. Dabire. "COVID-19 (Coronavirus): A Global Emergency Outbreak and Its Implicationns in India." International Journal of Zoology and Applied Biosciences (Rishan) 5, no. 2 (2020): 89-98. 
severe threat even before the COVID-19 outbreak because the government has been ignoring or even encouraging illegal mining and logging in the Amazon rainforest. These loggers and miners now risk bringing COVID-19 to remote populations. ${ }^{20}$

Another research explain the Brazil policy, written by Marli C. Cupertino and et.al., entitled "COVID-19 in Brazil: Epidemiological update and perspectives" on Asian Pacific Journal of Tropical Medicine, the discussion focused on Brazil health care system and the result show that Brazil can be considered as extremely vulnerable to the COVID-19 pandemic, in the event that stringent public health measures are not adequately implemented, cognizant of its continental dimension and ancestral socioeconomic inequality ubiquitous to the Brazilian society. ${ }^{21}$ Based on these literatures, it could be seen that there are some differences in Brazil and India's policy towards the COVID-19 crisis. The differences are caused by the difference policy priority. Thus, the author sees a pattern formed by the government's interest towards COVID-19 pandemic has influence actions from the policy.

\section{Methods}

The research method used in this research is a descriptive qualitative and comparative study. In this study intends to understand the phenomena about what is experienced by research subjects such as behavior, perception, motivation, actions, etc., holistically, and by means of descriptions in the form of words and languages, in a special natural context and by utilizing various natural methods. ${ }^{22}$ According to Sjachran Basah (1994), a comparison is a method of study or investigation by making comparisons between two or more objects of study to add and deepen knowledge about the object being studied. In comparison, there is an object to be compared that has been previously known, but this knowledge is not yet firm and clear. ${ }^{23}$

20 The Lancet. "COVID-19 in Brazil: "So what?"." The Lancet 395, no. 10235 (May 2020).

21 Cupertino, Marli C., Graziela A, Cupertino, Andreia P. Gomes, dan Nicholas Aj. Mayers. "COVID-19 in Brazil: Epidemiological update and perspectives.” Asian Pacific Journal of Tropical Medicine, 2020.

22 Moleong, Lexy J. Metodologi Penelitian Kualitatif. Bandung: PT Remaja Rosdakarya Offset, 2007.

23 Basah, Sjachran. Hukum Tata Negara Perbandingan. Jakarta: Bina Aksara, 1994. 


\section{Result and Discussion}

According to Michèle Flournoy as the head of geopolitical risk at Beacon Global Strategies, believe there is factors five determine coronavirus containment or devastation consist of: Public Health System, Culture and social cohesion, critical decision-making, border issues and leadership factors. ${ }^{24}$ Therefore, examining the five factors will help in finding a realization of competing priorities and focusing events from each government.

\section{Public Health System}

The World Health Organization defines a health system, as a system that:

[...] Includes all activities, which the basic purpose is to promote, restore or maintain health... and includes patients, health service's workers... inside organizations and in the community, and the health politics environment in which all health-related activities happen. ${ }^{25}$

The impact of national public health quality movement will be multifaceted. It will promote quality along all dimensions of the system with a special focus on population increase desired health outcomes and conditions in which the population can be healthy and fostering health equity. Poor nutrition has many other consequences, too many to quantify, including effects on the cognitive capacity of the population. ${ }^{26}$

Brazil is the most populous country in Latin America and the Caribbean. In 1988, Brazil established the Sistema Único da Saúde (SUS) promised ’health for all' - universal and comprehensive access to services free at the point of use. It is one of the biggest and most ambitious health programs in the world. ${ }^{27}$ However, during the COVID-19 pandemic, Brazil's health system is not prepared for it.

24 Flournoy, M., dan M. Morell. The 6 factors that determine coronavirus containment or devastation. 19 April 2020. https://www.washingtonpost.com/opinions/2020/04/19/6-factors-that-determine-coronavirus-containment-or-devastation/ (diakses August 27, 2020).

25 Kotler, P., J. Shalowitz, dan RJ Stevens. Strategic Marketing for the Health Area: the construction of a patient-oriented health system. Porto Alegre: Bookman, 2010.

26 Rubalcava, L.N., dan G. Teruel. The Role of Maternal Cognitive Ability in Child Health. Mexico: IDB Working Paper, 2004.

27 Greca, Daniel, dan Edward Fitzgerald. Healthcare in Brazil - Meeting Future Challenges . 2019. https:// home.kpmg/xx/en/home/insights/2019/04/meetin g-healthcare-challenges-in-brazil.html (August 27, 2020). 
Brazil's far-right president, Jair Bolsonaro, has accused his political foes and the press of purposefully "tricking" citizens about the dangers of coronavirus. ${ }^{28}$ Much worse, $\mathrm{Mr}$ Bolsonaro continues to oppose lockdown measures, arguing that social distancing will wreck the economy. In March 2020, Mr Bolsonaro made a speech calling on mayors and governors to roll back restrictions and belive that Brazilian lives have to go on, jobs must be kept and must get back to normal.

A two-term federal deputy, orthopedist Luiz Henrique Mandetta was responsible for the healthcare component of President Jair Bolsonaro's platform. ${ }^{29}$ Mandetta policy insisted that businesses should shut down and people stay home to reduce the spread of the virus. However, Mandetta insistence on facts and figures clashed with Bolsonaro's freewheeling approach, which often involves impromptu social media provocations. ${ }^{30}$ However, Brazilian President Jair Bolsonaro has fired Health Minister Luiz Henrique Mandetta after repeated clashes over how to handle the country's coronavirus epidemic. ${ }^{31}$

In May 2020, Brazilian Health Minister Nelson Teich, successor of Mr. Mandetta, resigned after less than a month in the job. He stepped down after he had publicly criticised a decree by Mr Bolsonaro allowing gyms and beauty parlours to reopen. According to Nelson Teich, Former Minister of Health of Brazil, arguing that Brazil needs a comprehensive testing system while assuring citizens that there would not be an "abrupt decision" on social distancing. ${ }^{32}$

The condition of nurses in Brazil are dying of COVID-19 faster than in any other country in the world, with almost 100 nurses dying from the disease per month. According to Dr Bart Janssens, the Médecins Sans Frontières (MSF) Emergency Coordinator, The astonishing death rates were due to the sheer numbers of very sick people needing intensive care treatment with oxygen and there not being enough intensive care unit (ICU) beds or staff. For several weeks,

28 Quinn, Colm. Bolsonaro Fires Brazil's Health Minister as Infections Grow . 17 April 2020. https:// foreignpolicy.com/2020/04/17/jair- bolsonaro-brazil-fires-heath-minister-mandetta- coronavirus-inections-grow/ (August 27, 2020).

29 Brazil Government. Health: Luiz Henrique Mandetta. 2020. http://www.brazil.gov.br/government/ministers/health (August 27, 2020).

30 Lopes, Marina. Brazil's Bolsonaro fires Health Minister Mandetta after differences over coronavirus response. 17 April 2020. http://www.brazil.gov.br/government/ministers/health (August 27, 2020).

31 Phillips, Dom. Bolsonaro fires popular health minister after dispute over coronavirus response . 2020. https://www.theguardian.com/world/2020/apr/16/bolsonar o-brazil-president-luiz-mandetta-healthminister (August 27, 2020).

32 BBC News. Coronavirus: Brazil's Bolsonaro sees second health minister quit. 15 May 2020. https:/ /www. bbc.com/news/world-latin-america-52682358 (August 27, 2020). 
hundreds of people were falling increasingly ill in non-ICU hospital wards, waiting for an ICU bed to become free. ${ }^{33}$

In fact, a military general with no experience remains health minister after Mr. Teich. Other members of the military on active duty are now part of the ministry as well. ${ }^{34}$ As the result of $\mathrm{Mr}$ Bolsonaro policy, the Brazilian pollster Ibope, found $48 \%$ of people in the city of São Paulo now considered his administration bad or awful. Another, by the Datafolha group, said 51\% of wealthy Brazilians and $46 \%$ of those with a university education were similarly unimpressed with his handling of the coronavirus crisis. ${ }^{35}$

Despite the authoritarian-minded leaders, president that not believes in the virus, Brazil's health regulator Anvisa has already approved trials for potential vaccines developed in the UK and Brazil has also made moves to secure access to possible vaccines, should they prove effective. ${ }^{36}$ According to Health Minister Eduardo Pazuello said the government had begun negotiations with US biotech firm Modern Inc to give Brazil priority access to a coronavirus vaccine in development. ${ }^{37}$ Brazil also begins advanced clinical testing of a Chinesedeveloped vaccine against the coronavirus. Brazil is also helping to carry out human trials of the experimental vaccine developed by Oxford University in Britain and pharmaceutical firm AstraZeneca. ${ }^{38}$ At least, the government tried to develop the vaccine by testing and cooperate with the other countries.

Meanwhile, similar condition with India that health system is unprepared for COVID-19 Pandemic. India's with the four main urban hubs account for nearly 125,000 Covid-19 cases and more than 4,200 deaths is around half the total fatalities nationwide. ${ }^{39}$ The situation has seen Prime Minister Narendra Modi

33 Médecins Sans Frontières. Brazil's COVID-19 nightmare is far from under control. 2020. https://www. msf.org/coronavirus-covid-19-nightmare-continues-brazil (August 27, 2020).

34 Gamba, Laura. Bolsonaro militarizes healthcare. 15 July 2020. https://www.aa.com.tr/en/americas/ bolsonaro-militarizes-healthcare/1910789 (August 27, 2020).

35 Phillips, Tom. Brazil's Jair Bolsonaro says coronavirus crisis is a media trick. 23 March 2020. https:// www.theguardian.com/world/2020/mar/23/brazils-jair-bolsonaro-says-coronavirus-crisis-is-a-mediatrick (August 27, 2020).

36 Reuters. Brazil health regulator Anvisa allows Chinese COVID-19 vaccine trial. 4 July 2020. https:// uk.reuters.com/article/us-health-coronavirus-brazil-sinovac/brazil-health-regulator-anvisa- allows-chinese-covid-19-vaccine-trial-idUKKBN24502Z (August 27, 2020).

37 Brito, Ricardo, dan Eduardo Simões. Brazil approves human trials for third COVID-19 vaccine. 22 July 2020. https://www.reuters.com/article/us-health-coronavirus- brazil-vaccine/brazil-approves-humantrials-for-third-covid-19-vaccine-idUSKCN24M2V5 (August 27, 2020).

38 Medical Press. Brazil set to test Chinese coronavirus vaccine. 21 July 2020. https://medicalxpress.com/news/2020-07-brazil-chinese-coronavirus-vaccine.html (August 27, 2020).

39 Krishnan, Murali. India's healthcare system under pressure as Covid-19 infections spike. 14 June 2020. 
call an emergency meeting with ministers and officials to review the country's COVID-19 response. However, India's poorly funded health care system, the government shells out less than 1.3 percent of GDP on health care each year, which means that the country faces devastating shortages even in the normal course of things. For every 1,000 people, the country has only 0.9 physicians and 1.7 nurses, while the global average is 1.6 doctors and 3.8 nurses. ${ }^{40}$

In fact, India has a severe shortage of healthcare workers. According to the Health Ministry data released in October 2019, there is one doctor for every 11,082 people, which is more than 10 times the doctor-patient ratio that the World Health Organization (WHO). The WHO mandates that the doctor to population ratio should be 1:1,000, while India had a 1:1,404 ratio as of February 2020 (Kapoor, 2020).

\section{Culture and Social Cohesion}

In developing countries there are social and cultural traditions that do not support economic development. Therefore, for development, there must be a free society with a strong middle class that is able to increase income through trade and commerce. These two factors produce modern economic growth in developed countries. Social construct has strong repercussions on the economy. Social organization of individual countries limits their economic development and social pathology is present in many countries. ${ }^{41}$

The local government in Maringa (Brazil) created a task force on 29 June to develop the Economic and Social Development Recovery Plan, based on a partnership between the city government and Sebrae (Brazilian Micro and Small Business Support Service).The plan aims to provide job creation, new investments, capacity building, stimulate law reform, benefits and credit access, among other initiatives to boost the economy. The plan is based on citizens' engagement and also involves, academia, civil society and the private sector. ${ }^{42}$

https://www.rfi.fr/en/international/20200614-india-s-healthcare-system-under-pressure-as-covid19-infections-spike (August 27, 2020).

40 Purohit, Kunal. India Has Bungled Its Coronavirus Crisis. 20 June 2020. https://foreignpolicy. com/2020/06/22/india-bungled-coronavirus-crisis-pandemic-reopening-health-care/ (August 27, 2020).

41 Tekic, Z. The missing link-Knowledge creation and inovation. Vienna: Proceedings of the 23rd International DAAAM Symposium, 2012, 229-232.

42 Maringá. Comitê do Plano da Retomada fará primeira reunião pela internet. 29 June 2020. http:/ / www2.maringa.pr.gov.br/site/index.php?sessao=8e54409f63558e\&id=36586 (August 29, 2020). 
On the other hand, the local government from Paraty (Brazil) launched a COVID-19 economic recovery plan that includes a municipal program to support informal workers with a specific project for culture incentive program based on public-private partnerships. In the mid-term, measures focus on decentralizing the tourism sector, as the city economy relies on touristic activities and gastronomy. In the long-term, measures involve renovation and refurbishment of public areas, such as the historic center and the pier, and the improvement of the sewage network in the historic centre in areas where there is no sanitation infrastructure. $^{43}$

According to Koi Tū, Deputy Director of the Centre for Informed Future, social cohesion as 'the willingness of members of a society to help one another as a basic shared value' In this way, social cohesion is at the heart of the kind of societal resilience that is required now more than ever. ${ }^{44}$ India's government cooperate with The World Bank to initiate the program called Accelerating India's COVID-19 Social Protection Response Program (PMGKY). The Program Development Objective of the proposed operation is to strengthen the capability of state and national governments in India to provide coordinated and adequate social protection to the poor and vulnerable from the impacts of the COVID-19 pandemic. $^{45}$

In India, Prime Minister Narendra Modi invoked the Mahabharat to suggest its people that India at war. The crisis wrought by Covid-19 is, thus, an apt critical juncture for us as a nation to commit to social solidarity at a time when social distancing is becoming the dominant discourse. ${ }^{46}$ However, that will be a major challenge for India, where successive governments have failed to build up adequate state capacity. Poor state capacity would make it particularly difficult to deal with the coronavirus pandemic if it should spread, Even governments with far greater administrative capacities. ${ }^{47}$

43 Paraty. Plano de Recuperação Econômica no município. 24 April 2020. http://www.paraty.rj.gov.br/ informativo/noticias/plano-de-recuperacao-economica-no-municipio (August 29, 2020).

44 Bardsley, Anne. Societal resilience - unpacking the black box. 2020. https://informedfutures. org/societal-resilience-unpacking-the-black-box/ (August 29, 2020).

45 Khan, Qaiser M., dan Shrayana Bhattacharya. Accelerating India's COVID-19 Social Protection Response Program (PMGKY) (P173943). Washington, D.C.: The World Bank, 2020.

46 Roy, Indrajit. Social cohesion while distancing. 31 March 2020. https://economictimes.indiatimes.com/ news/politics-and-nation/view-social-cohesion-while-distancing/articleshow/74919787.cms (August $16,2020)$.

47 Rajagopalan, Rajesh. India's COVID-19 fight needs a new social and economic behaviour. It's easier said than done. 20 March 2020. https://theprint.in/opinion/indias-covid-19-fight-needs-a-new-social-andeconomic-behaviour-its-easier-said-than-done/384240/ (August 20, 2020). 


\section{Critical Decision-Making}

Gary Klein describes the Recognition-Primed (or intuitive) decisionmaking model in his books titled "Sources of Power" and "Intuition at Work". ${ }^{48}$ This model assumes experience is the primary source of wisdom in decisionmaking, and results from many observations and studies of real-life cases of people actually making time critical decisions in the real world, rather than in laboratory conditions. It generally applies to crisis situations where time is very limited, such as an emergency room or fire fighting, rather than situations where time is not limited, and careful consideration is possible. ${ }^{49}$

Three months after the first COVID-19 case, several Brazilian states already are in critical condition, with their health systems overloaded, most of them above 80 percent occupancy or even collapsing. Nowadays, Brazil is considered the epidemic center of Latin America, occupying the second place in total number of cases and more recently in total number of deaths. ${ }^{50}$ Brazil is the world's secondworst affected nation after the US, with over 2 million cases. ${ }^{51}$

During complex crises, multiple values are at stake simultaneously and decisions must be immediate. For the COVID-19 pandemic, one of the choices has been between mitigating versus suppressing COVID-19. Conflict in Brazil between state governors and the president over the best approach to tame the epidemic. ${ }^{52}$ The COVID-19 outbreak may end up creating stronger censorship regimes in an attempt to curb the spread of disinformation. Brazilian President Jair Bolsonaro called the virus a "fantasy" and preventive measures "hysterical. ${ }^{53}$ President Jair Bolsonaro of Brazil has taken down content on certain technology platforms because they deemed it spread disinformation. ${ }^{54}$

48 Klein, G. Sources of Power. Cambridge, Massachusetts: MT Press, 1999.

49 Ogilvie, D. Strategic Decision Making in the 21st Century Army: A Creative Action-Based Approach. San Diego, CA: Fifty-eight Annual Academy of Management Best Paper Proceedings, 1998.

50 Tang, Yuanji, D.A. Tamires, dan N. Laureane. "Epidemiology of COVID-19 in Brazil: using a mathematical model to estimate the outbreak peak and temporal evolution.” Journal Emerging Microbes \& Infections (Taylor and Francis) 9 (2020).

51 Werneck, Guilherme Loureiro, dan Marilia Sá Carvalh. The COVID-19 pandemic in Brazil: chronicle of a health crisis foretold. Cadernos De Saude Publica (CSP), 2020.

52 Reuters. Brazil slashes growth, eyes healthcare collapse over coronavirus. 20 March 2020. https://www. nytimes.com/reuters/2020/03/20/world/americas/20reuters-health-coronavirus-brazil.html (August 19, 2020).

53 Roth, Kenneth. How Authoritarians Are Exploiting the COVID-19 Crisis to Grab Power. 3 April 2020. https://www.hrw.org/news/2020/04/03/how-authoritarians-are-exploiting-covid-19-crisis-grab-power (diakses August 29, 2020).

54 Ingram, David. Facebook, Twitter bar video of Brazilian president endorsing unproven antiviral drug. 1 March 2020. https://www.nbcnews.com/tech/social-media/facebook-removes-video-brazilian-presi- 
President Bolsonaro has denounced long-term local and state shutdowns. He says they will harm the economy and cause social unrest and proposes instead to limit quarantines to at-risk populations such as the elderly. He has called for reopening businesses that were closed by mayors and governors, and has suggested the antimalarial drug chloroquine could be an effective treatment for the virus. ${ }^{55}$ Additionally, at the Bolsonaro administration's request, Congress declared a "state of calamity," allowing the government to spend beyond normal limits. ${ }^{56}$ Calamity was created by the 200 Law of Fiscal Responsibility to grant the federal government mechanisms to free itself from the strict laws regulating public spending in exceptional, in this case the pandemic. The President Bolsonaro need to spending for health and jobs protection for Brazilian amid an expected drop in tax revenue..$^{57}$

Meanwhile, The Government of India organized a meeting of the Health Crisis Management Group and constituted a Group of Ministers (GOM) to plan, monitor and review the situation regularly and to ensure inter-ministerial coordination in January 8,2020. ${ }^{58}$ India's government also has several strategies of testing, tracing, tracking, quarantine and a containment measure; one of them is The Sero-survey on COVID-19. According to Balram Bhargava, Indian Council of Medical Research (ICMR) Director General, the sero-survey has two parts, the first being, the estimation of the fraction of population that has been infected with SARS-CoV-2 in general population. The second, being the estimation of the fraction of population that has been infected with the coronavirus in containment zones of hotspot cities. ${ }^{59}$

dent-endorsing-unproven-antiviral-drug-n1172566 (August 29, 2020).

55 Cheatham, Amelia. Skeptical Bolsonaro Clashes With Governors as Coronavirus Spreads in Brazil. 2 April 2020. https://www.cfr.org/in-brief/skeptical-bolsonaro-clashes-governors-coronavirus-spreadsbrazil (August 29, 2020).

56 Piller, Charles. 'This is insane!' Many scientists lament Trump's embrace of risky malaria drugs for coronavirus. March 26, 2020. https://www.sciencemag.org/news/2020/03/insane-many-scientists-lamenttrump-s-embrace-risky-malaria-drugs-coronavirus (August 29, 2020)

57 Ribeiro, Gustavo. Senate Approves "State of Calamity". 20 March 2020. https://brazilian.report/coronavirus-brazil-live-blog/2020/03/20/brazilian-senate-approves-state-of-calamity-against-covid-19/ (August 29, 2020).

58 Indian Embassy Jakarta. Looking ahead to life and work after COVID-19. 2020.https://www.indianembassyjakarta.gov.in/extra?id=eyJpdiI6InpXN2pJRUx1T1JwcmRXMFFOK0ZGSXc9PSIsInZhbHVIIjoiQk9QeFJcL3hsSmRLRTg5KzFxZ1I4OWc9PSIsIm1hYyI6ImIxOTUyOThjN2N mNzhiZjgzOThmNDA0YmU4YWVhYTEyM2IxMGYxZjIwZWE2ZDNiMzgyYjgyOGQwOWJjMjcwMDQifQ (August 29, 2020).

59 Business Standard. Covid-19 lockdown a success, no community transmission in India: ICMR. 11 June 2020. https://www.business-standard.com/article/current-affairs/covid-lockdown-successful-india-notin-community-transmission-stage-icmr-120061101143_1.html (August 29, 2020). 
The first part has been completed and the second is still ongoing. The ICMR in collaboration with state health departments, the National Centre launched the survey in May for Disease Control (NCDC) and the World Health Organization (WHO). The survey involves of a total of 83 districts with 26,400 people in India. However, a large proportion of the population is still susceptible and risk is higher in urban areas (1.09 times) and urban slums (1.89 times) than rural areas. ${ }^{60}$ Meanwhile, India decision on communication was failure to carry out contact tracing at mass scale was partly a reflection of poor state capacity, and partly a deliberate choice to show low COVID-19 figures. ${ }^{61}$ These poor choices only made the problem much worse, like letting a wound fester. Even though, the government's have the contract tracing based on smartphone app, however with a country where nearly 75 per cent of the population doesn't have a smartphone. ${ }^{62}$

Moreover, the role of leadership, then, is not to pretend that the unique values of the country will have it, but to support those that need help. The Indian Prime Minister, Modi, whose decision to quarantine the country with just a few hours' notice and with little apparent planning for the consequences of the decision on the poorest members of Indian society has seen a mass exodus from the cities that can only make the problem worse. ${ }^{63}$ This example reminds us to locate decisions in the appropriate context, in countries without a relatively sophisticated health system or the necessary social infrastructure, simply commanding people to stay home without providing any means for them to survive more than a few days, or instructing them to self-isolate, it makes no sense.

\section{Considering the entire country}

According to Michèle Flournoy, countries that have applied policies nationwide or thought through the implications that regional policies could have for the entire country have done better than those that have not done so. ${ }^{64}$ According to Bayu Krisnamurthi, who headed the National Committee for Avian

\footnotetext{
${ }^{60}$ Business Standard.

${ }^{61}$ Rukmini, S. ICMR data shows India's Covid testing is not in right shape -5 things that need fixing. 1 June 2020. https://theprint.in/opinion/icmr-data-shows-indias-covid-testing-is-not-in-right-shape5-things-that-need-fixing/433077/ (August 29, 2020).

62 Agence France-Presse. Smartphone Penetration Just 24 Percent in India, Claims Survey. 6 February 2020. https://gadgets.ndtv.com/mobiles/news/smartphone-penetration-just-24-percent-in-india-claims-survey-1989169 (August 29, 2020).

63 Grint, Keith. "Leadership, Management and Command in the time of the Coronavirus." Journal SAGE Public Health Emergency Collection, April 2020

64 Flournoy, M., Loc. Cit.
} 
Flu Control and Pandemic Preparedness in Indonesia, the terms lockdown and community quarantine are synonymous in that both are used interchangeably to refer to a type of quarantine in which all citizens in a certain region are prohibited from going in and out of the territory without official permission from authorities. ${ }^{65}$

The first confirmed case of a Brazilian infected with Coronavirus in February $26,{ }^{66}$ nearly a month after India's first case, came to light in Kerala on 30 January. After that on 1 and 2 February, 1-1 patients were found in Kerala. ${ }^{67}$ Brazilian President Jair Bolsonaro opposes the stringent lockdown some state governors have imposed on the Brazilian economy. The president has made it clear that the economy must come first and has fiercely fought the lockdowns imposed by state governors. ${ }^{68} \mathrm{He}$ has already lost two health ministers during the crisis: one was fired and the other resigned.

In March 2020, Brazil still does not have a mobilization and contingency plan for social distancing and collective and individual protection measures. Only with the Minimum Citizen Income could it prevent the economic death of the popular economy, starvation, and violence. ${ }^{69}$ However, the country has a set of authoritarian epidemiological laws, which allow the federal government to apply draconian measures without consulting and without allowing actions to defend regional or local interests. ${ }^{70}$ In May 2020, for the first time, Brazil's first major city to begin a coronavirus "lockdown" in São Luis. Lockdown measure covers São Luis and parts of three other municipalities with a total population of around

65 Fachriansyah, R., dan G. H. Cahya. COVID-19: Does Indonesia need a lockdown? It depends on how you define it. 19 March 2020. https://www.thejakartapost.com/news/2020/03/19/covid-19-does-indonesia-need-a-lockdown-it-depends-on-how-you-define-it.html (August 31, 2020).

66 Rodrigues, Alex. Brazil confirms first case of coronavirus. 26 February 2020. https://agenciabrasil.ebc.com.br/en/saude/noticia/2020-02/brazil-confirms-first-case-coronavirus (August 31, 2020).

67 Inventiva. There were 3 patients in February; No cases came for a month, 319 cases came after March 2, 454\% increase in last 10 days only. 21 March 2020. https://www.inventiva.co.in/stories/inventiva/therewere-3-patients-in-february-no-cases-came-for-a-month-319-cases-came-after-march-2-454-increase-inlast-10-days-only/ (August 31, 2020).

68 O’Grady, Mary Anastasia. Lockdown Puts Brazilian Lives at Risk. 17 May 2020. https://www.wsj.com/ articles/lockdown-puts-brazilian-lives-at-risk-11589743232 (diakses August 31, 2020).

69 Rodrigues, Heleno, Corrêa Filho, dan Ana Maria Segall. "Lockdown or participatory health surveillance? Lessons from the Covid-19." Journal Saude Debate 44, no. 124 (2020): 14.

70 Filho, Corrêa. Uma lei autoritária sem garantias de cidadania. 2019. http://cebes.org.br/2020/02/comentario-a-lei-do-coronavirus-2019-uma-lei-autoritaria-sem-garantias--de-cidadania/ (August 31, 2020). 
1.3 million people in the poor northeastern state of Maranhão. ${ }^{71} \mathrm{It}$ forbids people from going outside except to obtain groceries, medications or cleaning supplies

Meanwhile, India has gone through lockdown 1.0 (24 March to 14 April) lockdown 2.0 (15 March to 3 May), lockdown 3.0 (4 May to 17 May), and is in lockdown 4.0 from 18 May. So far, India has seen four times lockdown policy. ${ }^{72}$ The first lockdown on March 24, Prime Minister Modi announced that no one could leave home for 21 days. For the first time in India's history as a Republic, stoppage of all flight services and most public transport. And yet, continuity of essential services, including the power supplies, water, energy, food products, banking and delivery of essential goods. ${ }^{73}$ India has ensured greater and willful participation in the lockdown for its people through police rather than persuasion. The unique act to enforce the lockdown on poor hapless citizens, police coercion was used. This led to many incidents of people hitting back at the police. $^{74}$

The law invoked to deal with coronavirus in India, the Epidemic Diseases Act, 1897, has a dark history. According to Myron Echenberg, an accomplished scholar who wrote extensively on infectious diseases, noted that "the potential for abuse was enormous" in the Act. Since the 19th century makes it evident that the law has been used as a tool for abuse, oppression and tyranny. State abuse extended to public humiliation, abuse against women, public stripping and even violence against women, which led to historian, David Arnold, calling the Act "one of the most draconian pieces of sanitary legislation ever adopted in colonial India". ${ }^{75}$

The Epidemic Diseases Act refer to Section 4, absolves all responsibility for those acting under the directions of the Act. The beatings, abuse and humiliation will go unchecked since they were done in "good faith intended to be done under

71 Paraguassu, Lisandra. Major Brazilian cities set lockdowns as virus spreads. 6 May 2020. https://www.reuters.com/article/us-health-coronavirus-brazil-lockdown/major-brazilian-cities-set-lockdowns-as-virusspreads-idUSKBN22H2V3 (August 31, 2020).

72 Krishnan, Sanjana, Sahil Deo, dan Shardul Manurkar. 50 days of lockdown: Measuring India's success in arresting COVID-19. New Dehli: Observer Research Foundation (ORF) Report, 2020.

73 Gettleman, Jeffrey, dan Kai Schultz. Modi Orders 3-Week Total Lockdown for All 1.3 Billion Indians. 24 March 2020. https://www.nytimes.com/2020/03/24/world/asia/india-coronavirus-lockdown.html (August 31, 2020).

74 Vij, Shivam. Narendra Modi is selling a failed Covid lockdown as a success. 1 July 2020. https://theprint. in/opinion/narendra-modi-is-selling-a-failed-covid-lockdown-as-a-success/452191/ (August 31, 2020).

75 Sen, Agastya Sharma. India needs an overhaul of its outdated law to fight Covid-19. 2020. https:// www.dailyo.in/variety/police-brutality-epidemic-diseases-act-migrant-labourers-coronavirus-covid-19/ story/1/32666.html (August 31, 2020). 
this Act" ${ }^{76}$ Today, the police have been given free rein to harass, humiliate, abuse and assault. According to Section 144 of the Indian Penal Code (IPC), which prohibits the assembly of four or more people, to ensure that people don't venture out during the lockdown and to contain the spread of the coronavirus. If there any Indians violating section 144 could be arrested and detained by the police. ${ }^{77}$

\section{Leadership}

Leaders who act decisively and early, demonstrate competence in making tough decisions, communicate the facts clearly and consistently, and show empathy for those affected navigate crises far better than those who do not. ${ }^{78}$ In many countries including Brazil, India and Indonesia the governments set restrictions that have the same goal of restricting proximity between people, travel restrictions, school closures, workplace closures.

Oxford's public policy school, the Blavatnik School of Government, maintains the policy response data presented in the Table 4 Below. They publish it as the Coronavirus Government Response Tracker (OxCGRT). The Oxford COVID-19 Government Response Tracker (OxCGRT) systematically collects information on several different common policy responses that governments have taken to respond to the pandemic on nine indicators such as school closures and travel restrictions. ${ }^{79}$ The researchers also calculate a summary measure of the response metrics called the Government Stringency Index. The Government Stringency Index are: school closures; workplace closures; cancellation of public events; restrictions on public gatherings; closures of public transport; stay-athome requirements; public information campaigns; restrictions on internal movements; and international travel controls.

Table 3. The Government Response Stringency on COVID-19

\begin{tabular}{llll}
\hline Timeline & Brazil & India & Indonesia \\
\hline January 21, 2020 & 0,00 & 0,00 & 8,33 \\
February 21, 2020 & 5,56 & 10,19 & 28,70 \\
\hline
\end{tabular}

76 Sen.

77 Mukhopadhyay, Ankita. India: Police under fire for using violence to enforce coronavirus lockdown. 28 March 2020. https://www.dw.com/en/india-police-under-fire-for-using-violence-to-enforce-coronavirus-lockdown/a-52946717 (August 31, 2020).

78 Flournoy, M., Loc. Cit.

79 Blavatnik School of Government. Coronavirus Government Response Tracker. 2020. https://www.bsg. ox.ac.uk/research/research-projects/coronavirus-government-response-tracker (August 31, 2020). 


\begin{tabular}{llll}
\hline March 21, 2020 & 71,76 & 76,39 & 43,52 \\
April 21, 2020 & 74,54 & 96,30 & 71,76 \\
May 21, 2020 & 81,02 & 81,02 & 71,76 \\
June 21, 2020 & 77,31 & 76,39 & 68,06 \\
July 21, 2020 & 81,02 & 77,78 & 62,50 \\
\hline
\end{tabular}

Source: Our World in Data, $2020^{80}$

Rescaled to a value from 0 to 100 , the highest, which is the strictest response with value 100 . A higher score means a country has strict measures. Countries worst hit by the epidemic have a lower score. The study result shows that India's government strictest response is quite high compare to Brazil. Especially in April, when India first full lockdown were implemented. Meanwhile, Brazil highest score in May, when for the first time for Brazil's first major city to begin a coronavirus "lockdown" in São Luis.

Putting in place an effective mixture of policy responses will help deal with the pandemic and build momentum for growth in the future. Each countries has own policy to deal with pandemic, the decision will impact not only to the political and security, but also economic activity. In Brazil, Jair Bolsonaro, the president of Brazil got criticized lack of leadership amid COVID-19 crisis by saying the new virus was nothing but a "little flu" that has to be faced "realistically" and he country reported more than 1,000 deaths for four consecutive days. ${ }^{81}$

After his first year in office they have some of what they wanted. Brazil's economy has improved, and violent crime has fallen. Yet Mr Bolsonaro has not put to rest the doubts raised by his unlikely rise to power. ${ }^{82}$ However, during the COVID-19, a lot of criticized toward him and one of them is Bremmer act as CEO of the Eurasia Group. He stated that Jair Bolsonaro's decision to put the country's economic growth ahead of people's lives makes Brazil's President the most incompetent political leader in any democracy. ${ }^{83}$ The number of deaths in Brazil, which accounts for roughly half the population of South America, is now

80 Our World in Data. COVID-19: Government Response Stringency Index. 2020. https:/ / ourworldindata. org/policy-responses-covid (August 31, 2020).

81 McCaffrey, Darren. Analysis: Brazil and its lack of leadership amid COVID-19 crisis. 8 June 2020. https://www.euronews.com/2020/06/08/analysis-look-at-brazil-leadership-matters (August 31, 2020).

82 The Economist. A year of Jair Bolsonaro. 2 January 2020. https://www.economist.com/ leaders/2020/01/02/a-year-of-jair-bolsonaro (August 31, 2020).

83 Consultancy.lat. Jair Bolsonaro most incompetent political leader in a democracy. 1 June 2020. https://www.consultancy.lat/news/1062/jair-bolsonaro-most-incompetent-political-leaderin-a-democracy (diakses August 31, 2020) 
doubling every two weeks, compared with every two months in the hard-hit UK. ${ }^{84}$ It made his popularity ratings have tumbled and are now below 30 per cent; some 50 per cent of the population disapproves of his handling of the crisis. Thus, there is no doubt that $\mathrm{Mr}$ Bolsonaro is in political trouble. ${ }^{85}$

On the other hand, Prime Minister Narendra Modi has the highest popularity among the global leaders as per a recent analysis done by pollster Morning Consult. As of April 14, his net approval rating is 68, by leads the world in combating COVID-19. Ensuring safety and security for the Indian people. ${ }^{86}$ Even Google CEO, Sundar Pichai appreciated the prime minister's leadership skills in order to combat the novel coronavirus outbreak in the country. ${ }^{87}$

The August 2020 edition of the Mood of the Nation survey has found that 77 percent of the surveyed people are satisfied with PM Modi's performance during the coronavirus crisis. ${ }^{88}$ For example, as Modi trained his focus on the fact that India today manufactures great volumes of PPE and test kits, has set up a large number of hospital beds and plans to improve logistics. ${ }^{89}$

The MDSD approach is the opposite - the task is to locate similar variables across different cases. In this research the similar variables including: Public Health System, Culture and Social Cohesion, Critical Decision Making, Considering the Entire Country and Leadership across different cases in Brazil and India. Brazil has a partial-lockdown system and India has a full-lockdown system, yet in both countries there is a high numbers of death rate and confirmed cases.

${ }^{84}$ Financial Times. Coronavirus tracked: the latest figures as countries reopen. 4 August 2020. https:/ /www. ft.com/content/a2901ce8-5eb7-4633-b89c-cbdf5b386938 (August 31, 2020).

85 Rachman, Gideon. Jair Bolsonaro's populism is leading Brazil to disaster. 5 May 2020. https://www. ft.com/content/c39fadfe-9e60-11ea-b65d-489c67b0d85d (August 31, 2020).

86 Nadda, J. P. PM Modi ranked top among global leaders in fight against COVID-19. 22 April 2020. https://economictimes.indiatimes.com/news/politics-and-nation/pm-modi-ranked-top-among-globalleaders-in-fight-against-covid-19-j-p-nadda/articleshow/75294227.cms?from=mdr (August 16, 2020).

87 Pichai, Sundar. Google CEO appreciates PM Modi's leadership in battle against Covid-19. 13 July 2020. https://www.livemint.com/news/india/google-ceo-appreciates-pm-modi-s-leadership-in-battle-againstcovid-19-11594634060016.html (diakses August 16, 2020).

88 India Today. 77\% Indians satisfied with PM Modi's handling of Covid-19 crisis, shows MOTN survey. 7 August 2020. https://www.indiatoday.in/magazine/mood-of-the-nation/story/20200817-77-per-cent-indians-satisfied-pm-modi-coronavirus-crisis-motn-survey-1708927-2020-08-07 (August 16, 2020).

89 Mukunth, Vasudevan. How True Is Modi's Claim That His Decisions Saved India From the Worst of COVID-19? 28 July 2020. https://thewire.in/government/how-true-is-modis-claim-that-his-decisionssaved-india-from-the-worst-of-covid-19 (August 16, 2020). 
Table 2. Comparative of Government's Policy Priorities on COVID-19 Pandemic.

\begin{tabular}{|c|c|c|}
\hline Features & Brazil & India \\
\hline $\begin{array}{l}\text { Public Health } \\
\text { System }^{90}\end{array}$ & $\begin{array}{l}\text { Rank: } 63 \text { out of } 89 \\
\text { countries Health Care } \\
\text { Index (Overall): } 36.31\end{array}$ & $\begin{array}{l}\text { Rank: } 19 \text { out of } 89 \\
\text { countries Health Care } \\
\text { Index (Overall): } 52.1\end{array}$ \\
\hline $\begin{array}{l}\text { Culture and Social } \\
\text { Cohesion }\end{array}$ & $\begin{array}{l}\text { 1. Economic and Social } \\
\text { Development Recovery } \\
\text { Plan } \\
\text { 2. Sebrae (Brazilian Micro } \\
\text { and Small Business } \\
\text { Support Service). }\end{array}$ & $\begin{array}{l}\text { Social Protection Response } \\
\text { Program (PMGKY) }\end{array}$ \\
\hline $\begin{array}{l}\text { Critical Decision } \\
\text { Making }\end{array}$ & $\begin{array}{l}\text { 1. Stronger censorship } \\
\text { regimes } \\
\text { 2. Denounced long- } \\
\text { term local and state } \\
\text { shutdowns } \\
\text { 3. Declared a "state of } \\
\text { calamity" }\end{array}$ & $\begin{array}{l}\text { 1. The Sero-survey on } \\
\text { COVID-19. } \\
\text { 2. The contract tracing } \\
\text { based on smartphone } \\
\text { app } \\
\text { 3. self-isolate \& full } \\
\text { lockdown }\end{array}$ \\
\hline $\begin{array}{l}\text { Considering the } \\
\text { Entire Country }{ }^{91}\end{array}$ & $\begin{array}{l}\text { Partial Lockdown: } \\
\text { Less than a month }\end{array}$ & $\begin{array}{l}\text { Full Lockdown: } \\
\text { More than a month }\end{array}$ \\
\hline $\begin{array}{l}\text { Leadership } \\
\text { (According to }\end{array}$ & President Jair Bolsonaro & President Narendra Modi \\
\hline $\begin{array}{l}\text { Forbes "The World's } \\
\text { Most Powerful } \\
\text { People" } 92\end{array}$ & $\begin{array}{l}\text { Rank \#50 } \\
\text { Out of } 75 \text { Finalist }\end{array}$ & $\begin{array}{l}\text { Rank \#9 Out of } 75 \\
\text { Finalist (Forbes, 2020) }\end{array}$ \\
\hline Outcome & & \\
\hline
\end{tabular}

90 Ireland, Sophie. Revealed: Countries With The Best Health Care Systems, 2019. 5 August 2019. https:// ceoworld.biz/2019/08/05/revealed-countries-with-the-best-health-care-systems-2019/\#: :text $=\quad(\mathrm{Au}-$ gust 27, 2020).

91 Garda World. Brazil: Quarantine in São Paulo extended. 20 April 2020. https://www.garda.com/crisis24/news-alerts/334111/brazil-quarantine-in-sao-paulo-extended-through-may-10-update-13 (August $27,2020)$

92 Forbes. The World's Most Powerful People. 4 August 2020. https://www.forbes.com/powerful-people/ list/ (diakses August 27, 2020). 


\begin{tabular}{lll}
\hline Cumulative & 3.36 million cases as of & 2.7 million cases as of 18 \\
confirmed cases $^{93}$ & 18 August, 2020 & August, 2020 \\
Cumulative & 108,536 deaths as of 18 & 51,797 deaths as of 18 \\
confirmed & August 2020 & August 2020 \\
COVID-19 deaths ${ }^{94}$ & &
\end{tabular}

Economic Growth

2020

-1.5 percent

0.7 percent

Quarter $1(\mathrm{Q} 1)^{95}$

In comparative analysis usually through three stages, namely: the first stage is a descriptive activity to look for information, the second stage is to sort out information based on certain classifications, and the third stage analyzes the results of the classification to see the order and relationship between various variables. Comparative studies can give us perspectives on institutions, good and $\mathrm{bad}$, and what causes these institutions to form. ${ }^{96}$

The types of comparable, in this case, is Most Different System Designs (MDSD), compare countries that do not share any common features apart from the political outcome to be explained and one or two of the explanatory factors seen to be important for that outcome. ${ }^{97} \mathrm{MDSD}$ allows the researcher to distill out the common elements from a diverse set of countries that have greater explanatory power. ${ }^{98}$ For MDSD on the right-hand side of the table, the countries have inherently different features (a through i) but share the same key explanatory factor (x) as well as the presence of the outcome to be explained (y). In this system, the outcome to be explained is due to the presence of the key explanatory factor in all the countries $(\mathrm{x}) .{ }^{99}$

93 Our World in Data. Cumulative confirmed COVID-19 cases. 6 August 2020. https://ourworldindata. org/coronavirus/country/indonesia?country $=\sim$ IDN\# cumulative-confirmed-cases-how-rapidly-havethey-increased-compared-to-other-countries (August 6, 2020).

94 Our World in Data. Cumulative confirmed COVID-19 deaths. 6 August 2020. https:// ourworldindata. org/covid-deaths\#what-is-the-total-number-of-confirmed-deaths (August 6, 2020).

95 OECD. News Release: G20 GDP growth Quarterly National Accounts: Record fall in G20 GDP in first quarter of 2020. 11 June 2020. https://www.oecd.org/sdd/na/g20-gdp-growth-Q1-2020.pdf (August $27,2020)$.

96 Mas'oed, Mohtar, dan Colin MacAndrews. Perbandingan Sistem Politik. Yogyakarta: Gadjah Mada University Press, 2008

97 Landman, Todd. Issues and Methods in Comparative Politics: An Introduction. London: Routledge, 2013.

98 Collier, D. 'The Comparative Method', in A. Finifter (ed.) Political Science: The State of the Discipline . Washington, D.C.: The American Political Science Association, 1993.

99 Landman, 75. 
The economic interest as factors that affect the context of policymaking for Brazil and India. The politics of the moment are only a piece of the policy environment, however, economics as of a major factor. Money plays a large role in this situation. When the economy is not performing well, the leaders are often focused on "fixing" the economy rather than priorities the country or the citizens. While, India seems identified health and economic self-reliance as the key priorities for his government.

\section{Conclusion}

India and Brazil, the most populated nations, rank high in the global COVID-19 count. Both are middle-income growing economies, having densely populated cities dotted with large slums, and battling a rising pandemic burden. But the two countries differ on one very key consideration - Brazilian President Jair Bolsonaro is stridently anti-lockdown, even joining protests against governors who've imposed lockdowns, such as the governor of Sao Paulo. India, on the other hand, has been under central lockdown since March 25. The Similarities between the two countries are high, including demographic, economic, and health indicators, making them a fit case for comparative analysis.

First, regarding the neglect of the healthcare system, inhumane and congested living conditions for the urban poor. Numbers show India has consistently added far fewer cases every day than Brazil. However, they also show that India's lockdown has not been as successful in reducing the number of cases as hoped, compared to Brazil without a lockdown. In fact, since the announcement of the lockdown, the average daily growth rate of cases has been slightly higher in India than Brazil, indicating that a lockdown is important, but it does not necessarily halt the spread of the virus. The key economic policies announced in response to the ongoing pandemic and assess their likely implications. Furthermore, there is evidence that both of the governments are struggling for economic priorities because of economic recessions are scarred and achieve poorer economic outcomes over the longer term.

\section{Reference}

Agence France-Presse. Smartphone Penetration Just 24 Percent in India, Claims Survey. 6 February 2020. https://gadgets.ndtv.com/mobiles/ news/smartphone-penetration-just-24-percent-in-india-claimssurvey-1989169 (August 29, 2020). 
Bardsley, Anne. Societal resilience - unpacking the black box. 2020. https:// informedfutures.org/societal-resilience-unpacking-the-black-box/ (August 29, 2020).

Basah, Sjachran. Hukum Tata Negara Perbandingan. Jakarta: Bina Aksara, 1994. BBC News. Coronavirus: Brazil's Bolsonaro sees second health minister quit. 15 May 2020. https://www.bbc.com/news/world-latin-america-52682358 (August 27, 2020).

BBC News. oronavirus: Brazil becomes second country to pass 50,000 deaths. 22 June 2020. https://www.bbc.com/news/world- latin-america-53132225 (August 19, 2020).

Blavatnik School of Government. Coronavirus Government Response Tracker. 2020. https://www.bsg.ox.ac.uk/research/research-projects/coronavirusgovernment-response-tracker (August 31, 2020).

Brazil Government. Health: Luiz Henrique Mandetta. 2020. http://www.brazil. gov.br/government/ministers/health (August 27, 2020).

Brito, Ricardo, dan Eduardo Simões. Brazil approves human trials for third COVID-19 vaccine. 22 July 2020. https://www.reuters.com/article/ushealth-coronavirus- brazil-vaccine/brazil-approves-human-trials-forthird-covid-19-vaccine-idUSKCN24M2V5 (August 27, 2020).

Business Standard. Covid-19 lockdown a success, no community transmission in India: ICMR. 11 June 2020. https://www.business-standard.com/article/ current-affairs/covid-lockdown-successful-india-not-in-communitytransmission-stage-icmr-120061101143_1.html (August 29, 2020).

CGTN.COVID-19 Global Roundup: Brazil facing 'crisis moment. 2020. https:// news.cgtn.com/news/2020-06-20/COVID-19-Global- Roundup-Brazilfacing-crisis-moment--RtEYfn1C4E/index.html (August 19, 2020).

Cheatham, Amelia. Skeptical Bolsonaro Clashes With Governors as Coronavirus Spreads in Brazil. 2 April 2020. https://www.cfr.org/in-brief/skepticalbolsonaro-clashes-governors-coronavirus-spreads-brazil (August 29, 2020).

Collier, D. 'The Comparative Method', in A. Finifter (ed.) Political Science: The State of the Discipline. Washington, D.C.: The American Political Science Association, 1993.

Consultancy.lat. Jair Bolsonaro most incompetent political leader in a democracy. 1 June 2020. https://www.consultancy.lat/news/1062/jair-bolsonaro-mostincompetent-political-leader-in-a-democracy (August 31, 2020). 
Cupertino, Marli C., Graziela A, Cupertino, Andreia P. Gomes, dan Nicholas Aj. Mayers. "COVID-19 in Brazil: Epidemiological update and perspectives." Asian Pacific Journal of Tropical Medicine, 2020.

David, M., Lokeshkumar, dan Suraj S. Dabire. "COVID-19 (Coronavirus): A Global Emergency Outbreak and Its Implicationns in India."International Journal of Zoology and Applied Biosciences (Rishan) 5, no. 2 (2020): 8998.

Ducharme, J. World Health Organization Declares COVID-19 a 'Pandemic.' Here's What That Means. 11 March 2020. https://time.com/5791661/ who-coronavirus-pandemic-declaration/ (August 19, 2020).

Fachriansyah, R., dan G. H. Cahya. COVID-19: Does Indonesia need a lockdown? It depends on how you define it. 19 March 2020. https://www. thejakartapost.com/news/2020/03/19/covid-19-does-indonesia-need-alockdown-it-depends-on-how-you-define-it.html (August 31, 2020).

Filho, Corrêa. Uma lei autoritária sem garantias de cidadania. 2019. http:// cebes.org.br/2020/02/comentario-a-lei-do-coronavirus-2019-uma-leiautoritaria-sem-garantias--de-cidadania/ (August 31, 2020).

Financial Times. Coronavirus tracked: the latest figures as countries reopen. 4 August 2020. https://www.ft.com/content/a2901ce8-5eb7-4633-b89ccbdf5b386938 (August 31, 2020).

Flournoy, M., dan M. Morell. The 6 factors that determine coronavirus containment or devastation. 19 April 2020. https://www.washingtonpost. com/opinions/2020/04/19/6-factors-that-determine-coronaviruscontainment-or-devastation/ (August 27, 2020).

Forbes. The World's Most Powerful People. 4 August 2020. https://www.forbes. com/powerful-people/list/ (August 27, 2020).

Gamba, Laura. Bolsonaro militarizes healthcare. 15 July 2020. https://www. aa.com.tr/en/americas/bolsonaro-militarizes-healthcare/1910789 (August 27, 2020).

Garda World. Brazil: Quarantine in São Paulo extended. 20 April 2020. https:// www.garda.com/crisis24/news-alerts/334111/brazil-quarantine-in-saopaulo-extended-through-may-10-update-13 (August 27, 2020).

Gettleman, Jeffrey, dan Kai Schultz. Modi Orders 3-Week Total Lockdown for All 1.3 Billion Indians. 24 March 2020. https://www.nytimes. com/2020/03/24/world/asia/india-coronavirus-lockdown.html (August $31,2020)$. 
Goldstone , Jack A. Rise of the TIMBIs: Turkey, India, Mexico, Brazil and Indonesia. Washington, D.C: Brookings Institution, 2011.

Greca, Daniel, dan Edward Fitzgerald. Healthcare in Brazil - Meeting Future Challenges . 2019. https://home.kpmg/xx/en/home/insights/2019/04/ meetin g-healthcare-challenges-in-brazil.html (August 27, 2020).

Grint, Keith. "Leadership, Management and Command in the time of the Coronavirus."Journal SAGE Public Health Emergency Collection, April 2020.

Hackett, Conrad. Which 7 countries hold half the world's population? 2020. https:/www.pewresearch.org/fact- $\operatorname{tank} / 2018 / 07 / 11 /$ world-populationday/\#: :text=China\%20has\%20the\%20world's\%20largest,have\% 20fewer\%20people\%20than\%20India (August 19, 2020).

Hospita, M. E. Coronavirus cases in Southeast Asia top 150,000. 30 June 2020. https://www.aa.com.tr/en/asia-pacific/coronavirus-cases-in-southeastasia-top-150- 000/1894835 (August 19, 2020).

IMF. World Economic Outlook. June 2020. https://www.imf.org/en/Publications/WEO/Issues/2020/0 6/24/WEOUpdateJune2020 (August 19, 2020).

India Today. 77\% Indians satisfied with PM Modi's handling of Covid-19 crisis, shows MOTN survey. 7 August 2020. https://www.indiatoday.in/magazine/mood-of-the-nation/story/20200817-77-per-cent-indians-satisfiedpm-modi-coronavirus-crisis-motn-survey-1708927-2020-08-07 (August 16, 2020).

Indian Embassy Jakarta. Looking ahead to life and work after COVID-19. 2020. https://www.indianembassyjakarta.gov.in/extra?id=eyJpdiI6InpXN2pJR Ux1T1JwcmRXMFFOK0ZGSXc9PSIsInZhbHVIIjoiQk9QeFJcL3hsSmRL RTg5KzFxZ1I4OWc9PSIsIm1hYyI6ImIxOTUyOThjN2NmNzhiZjgzOTh

mNDA0YmU4YWVhYTEyM2IxMGYxZjIwZWE2ZDNiMzgyYjgyOGQw OWJjMjcwMDQifQ (August 29, 2020).

Ingram, David. Facebook, Twitter bar video of Brazilian president endorsing unproven antiviral drug. 1 March 2020. https://www.nbcnews.com/tech/ social-media/facebook-removes-video-brazilian-president-endorsing-unproven-antiviral-drug-n1172566 (August 29, 2020).

Inventiva. There were 3 patients in February; No cases came for a month, 319 cases came after March 2, 454\% increase in last 10 days only. 21 March 
2020. https://www.inventiva.co.in/stories/inventiva/there-were-3-patients-in-february-no-cases-came-for-a-month-319-cases-came-aftermarch-2-454-increase-in-last-10-days-only/ (August 31, 2020).

Ireland, Sophie. Revealed: Countries With The Best Health Care Systems, 2019. 5 August 2019. https://ceoworld.biz/2019/08/05/revealed-countrieswith-the-best-health-care-systems-2019/\#: :text= (August 27, 2020).

Kachroo, Varsha. "Novel Coronavirus (COVID-19) in India: Current Scenario." International Journal of Research and Review 7, no. 3 (2020): 435-447.

Kapoor, Cheena. COVID-19: Is Indian healthcare system heading for collapse? 10 June 2020. https://www.aa.com.tr/en/asia-pacific/covid-19-is-indianhealthcare-system-heading-for-collapse/1871871 (August 27, 2020).

Khan, Qaiser M., dan Shrayana Bhattacharya. Accelerating India's COVID-19 Social Protection Response Program (PMGKY) (P173943). Washington, D.C.: The World Bank, 2020.

Klein, G. Sources of Power. Cambridge, Massachusetts: MT Press, 1999.

Kliman, Daniel M., dan Richard Fontaine. Global Swing States Brazil, India, Indonesia, Turkey and the Future of International Order. Washington D.C $\therefore$ Center for a New American Security, 2012.

Kotler, P., J. Shalowitz, dan RJ Stevens. Strategic Marketing for the Health Area: the construction of a patient-oriented health system. Porto Alegre: Bookman, 2010.

Kraft, Michael E., dan Scott R. Furlong. Defining U.S. Public Policy Making. California: SAGE Publications, Inc., 2019.

Krishnan, Murali. India's healthcare system under pressure as Covid-19 infections spike. 14 June 2020. https://www.rfi.fr/en/international/20200614india-s-healthcare-system-under-pressure-as-covid-19-infections-spike (August 27, 2020).

Krishnan, Sanjana, Sahil Deo, dan Shardul Manurkar. 50 days of lockdown: Measuring India's success in arresting COVID-19. New Dehli: Observer Research Foundation (ORF) Report, 2020.

Landman, Todd. Issues and Methods in Comparative Politics: An Introduction. London: Routledge, 2013.

Lopes, Marina. Brazil's Bolsonaro fires Health Minister Mandetta after differences over coronavirus response. 17 April 2020. http://www.brazil.gov.br/ government/ministers/health (August 27, 2020). 
Malhan, Meera, Navneet Manchanda, dan Aryaman Bhatia. Lessons from India's jobless growth story. 2019. https://www.thestatesman.com/opinion/ lessons-indias-jobless-growth-story-1502835431.html (August 19, 2020).

Maringá. Comitê do Plano da Retomada fará primeira reunião pela internet. 29 June 2020. http://www2.maringa.pr.gov.br/site/index.php?sessao $=8 \mathrm{e} 5440$ 9f63558e\&id=36586 (diakses August 29, 2020).

Mas'oed, Mohtar, dan Colin MacAndrews. Perbandingan Sistem Politik. Yogyakarta: Gadjah Mada University Press, 2008.

McCaffrey, Darren. Analysis: Brazil and its lack of leadership amid COVID-19 crisis. 8 June 2020. https://www.euronews.com/2020/06/08/analysis-lookat-brazil-leadership-matters (diakses August 31, 2020).

Médecins Sans Frontières. Brazil's COVID-19 nightmare is far from under control. 2020. https://www.msf.org/coronavirus-covid-19-nightmare-continues-brazil (August 27, 2020).

Medical Press. Brazil set to test Chinese coronavirus vaccine. 21 July 2020. https://medicalxpress.com/news/2020-07-brazil-chinese-coronavirusvaccine.html (diakses August 27, 2020).

Moleong, Lexy J. Metodologi Penelitian Kualitatif. Bandung: PT Remaja Rosdakarya Offset, 2007.

Mukhopadhyay, Ankita. India: Police under fire for using violence to enforce coronavirus lockdown. 28 March 2020. https://www.dw.com/en/ india-police-under-fire-for-using-violence-to-enforce-coronaviruslockdown/a-52946717 (August 31, 2020).

Mukunth, Vasudevan. How True Is Modi's Claim That His Decisions Saved India From the Worst of COVID-19? 28 July 2020. https://thewire.in/government/how-true-is-modis-claim-that-his-decisions-saved-india-fromthe-worst-of-covid-19 (August 16, 2020).

Nadda, J. P. PM Modi ranked top among global leaders in fight against COVID-19. 22 April 2020. https://economictimes.indiatimes.com/news/ politics-and-nation/pm-modi-ranked-top-among-global-leaders-infight-against-covid-19-j-p-nadda/articleshow/75294227.cms?from=mdr (August 16, 2020).

Nugroho, Riant. Public Policy. Jakarta: PT Elex Media Komputindo, 2009.

O'Grady, Mary Anastasia. Lockdown Puts Brazilian Lives at Risk. 17 May 2020. https://www.wsj.com/articles/lockdown-puts-brazilian-lives-atrisk-11589743232 (August 31, 2020). 
OECD. News Release: G20 GDP growth Quarterly National Accounts: Record fall in G20 GDP in first quarter of 2020.11 June 2020. https://www.oecd. org/sdd/na/g20-gdp-growth-Q1-2020.pdf (August 27, 2020).

Ogilvie, D. Strategic Decision Making in the 21st Century Army: A Creative Action-Based Approach. San Diego, CA: Fifty-eight Annual Academy of Management Best Paper Proceedings, 1998.

Our World in Data. COVID-19: Government Response Stringency Index. 2020. https://ourworldindata.org/policy-responses-covid (August 31, 2020).

Our World in Data. Cumulative confirmed COVID-19 cases. 6 August 2020. https://ourworldindata.org/coronavirus/country/indonesia?country= IDN\#cumulative-confirmed-cases-how-rapidly-have-they-increasedcompared-to-other-countries (August 6, 2020).

- Cumulative confirmed COVID-19 deaths. 6 August 2020. https:// ourworldindata.org/covid-deaths\#what-is-the-total-number-ofconfirmed-deaths (August 6, 2020).

Paraguassu, Lisandra. Major Brazilian cities set lockdowns as virus spreads. 6 May 2020. https://www.reuters.com/article/us-health-coronavirusbrazil-lockdown/major-brazilian-cities-set-lockdowns-as-virus-spreadsidUSKBN22H2V3 (August 31, 2020).

Paraty. Plano de Recuperação Econômica no município. 24 April 2020. http:// www.paraty.rj.gov.br/informativo/noticias/plano-de-recuperacaoeconomica-no-municipio (August 29, 2020).

Phillips, Dom. Bolsonaro fires popular health minister after dispute over coronavirus response . 2020. https://www.theguardian.com/world/2020/ apr/16/bolsonar o-brazil-president-luiz-mandetta-health-minister (August 27, 2020).

Phillips, Tom. Brazil's Jair Bolsonaro says coronavirus crisis is a media trick. 23 March 2020. https://www.theguardian.com/world/2020/mar/23/brazils -jair-bolsonaro-says-coronavirus-crisis-is-a-media-trick (August 27, 2020).

Pichai, Sundar. Google CEO appreciates PM Modi's leadership in battle against Covid-19. 13 July 2020. https://www.livemint.com/news/india/ google-ceo-appreciates-pm-modi-s-leadership-in-battle-againstcovid-19-11594634060016.html (diakses August 16, 2020). 
Piller, Charles. 'This is insane!' Many scientists lament Trump's embrace of risky malaria drugs for coronavirus. 26 March 2020. https://www.sciencemag. $\mathrm{org} /$ news/2020/03/insane-many-scientists-lament-trump-s-embracerisky-malaria-drugs-coronavirus (diakses August 29, 2020).

Purohit, Kunal. India Has Bungled Its Coronavirus Crisis. 20 June 2020. https://foreignpolicy.com/2020/06/22/india-bungled-coronavirus-crisispandemic-reopening-health-care/ (diakses August 27, 2020).

PwC. The Long View How will the global economic order change by 2050. Summary Report, London: PricewaterhouseCoopers LLP, 2017.

Quinn, Colm. Bolsonaro Fires Brazil's Health Minister as Infections Grow . 17 April 2020. https://foreignpolicy.com/2020/04/17/jair- bolsonaro-brazilfires-heath-minister-mandetta- coronavirus-inections-grow/ (August 27, 2020).

Rachman, Gideon. Jair Bolsonaro's populism is leading Brazil to disaster. 5 May 2020. https://www.ft.com/content/c39fadfe-9e60-11ea-b65d489c67b0d85d (diakses August 31, 2020).

Rajagopalan, Rajesh. India's COVID-19 fight needs a new social and economic behaviour. It's easier said than done. 20 March 2020. https://theprint. in/opinion/indias-covid-19-fight-needs-a-new-social-and-economicbehaviour-its-easier-said-than-done/384240/ (August 20, 2020).

Reuters. Brazil health regulator Anvisa allows Chinese COVID-19 vaccine trial. 4 July 2020. https://uk.reuters.com/article/us-health-coronavirus-brazilsinovac/brazil-health-regulator-anvisa- allows-chinese-covid-19-vaccinetrial-idUKKBN24502Z (August 27, 2020).

Reuters. Brazil slashes growth, eyes healthcare collapse over coronavirus. 20 March 2020. https://www.nytimes.com/reuters/2020/03/20/world/ americas/20reuters-health-coronavirus-brazil.html (August 19, 2020).

Ribeiro, Gustavo. Senate Approves "State of Calamity”. 20 March 2020. https:// brazilian.report/coronavirus-brazil-live-blog/2020/03/20/braziliansenate-approves-state-of-calamity-against-covid-19/ (August 29, 2020).

Rodrigues, Alex. Brazil confirms first case of coronavirus. 26 February 2020. https://agenciabrasil.ebc.com.br/en/saude/noticia/2020-02/brazilconfirms-first-case-coronavirus (diakses August 31, 2020).

Rodrigues, Heleno, Corrêa Filho, dan Ana Maria Segall. "Lockdown or participatory health surveillance? Lessons from the Covid-19." Journal Saude Debate 44, no. 124 (2020): 14. 
Roth, Kenneth. How Authoritarians Are Exploiting the COVID-19 Crisis to Grab Power. 3 April 2020. https://www.hrw.org/news/2020/04/03/howauthoritarians-are-exploiting-covid-19-crisis-grab-power (August 29, 2020).

Roy, Indrajit. Social cohesion while distancing. 31 March 2020. https:// economictimes.indiatimes.com/news/politics-and-nation/view-socialcohesion-while-distancing/articleshow/74919787.cms (August 16, 2020).

Rubalcava, L.N., dan G. Teruel. The Role of Maternal Cognitive Ability in Child Health. Mexico: IDB Working Paper, 2004.

Rukmini, S. ICMR data shows India's Covid testing is not in right shape 5 things that need fixing. 1 June 2020. https://theprint.in/opinion/icmrdata-shows-indias-covid-testing-is-not-in-right-shape-5-things-thatneed-fixing/433077/ (August 29, 2020).

Sabatier, Paul. Theories of the Policy Process. New York: Routledge, 2007.

Schipani, Andres. Brazil's first-quarter GDP falls $1.5 \%$ as Covid-19 cases climb. 2020. https://www.ft.com/content/d0461a1f- 84be-4704-91f6da02d792a810 (August 19, 2020).

Sen, Agastya Sharma. India needs an overhaul of its outdated law to fight Covid-19. 2020. https://www.dailyo.in/variety/police-brutality-epidemicdiseases-act-migrant-labourers-coronavirus-covid-19/story/1/32666.html (August 31, 2020).

Tang, Yuanji, D.A. Tamires, dan N. Laureane. "Epidemiology of COVID-19 in Brazil: using a mathematical model to estimate the outbreak peak and temporal evolution.”Journal Emerging Microbes \& Infections (Taylor and Francis) 9 (2020).

Tekic,Z.The missing link-Knowledge creation and inovation.Vienna:Proceedings of the 23rd International DAAAM Symposium, 2012, 229-232.

The Economist. A year of Jair Bolsonaro. 2 January 2020. https://www.economist. com/leaders/2020/01/02/a-year-of-jair-bolsonaro (August 31, 2020).

The Lancet. “COVID-19 in Brazil: “So what?”.”The Lancet 395, no. 10235 (May 2020).

Vij, Shivam. Narendra Modi is selling a failed Covid lockdown as a success. 1 July 2020. https://theprint.in/opinion/narendra-modi-is-selling-a-failedcovid-lockdown-as-a-success/452191/ (August 31, 2020). 
Werneck, Guilherme Loureiro, dan Marilia Sá Carvalh. The COVID-19 pandemic in Brazil: chronicle of a health crisis foretold. Cadernos De Saude Publica (CSP), 2020.

Yiwei, Hu. Graphics: How COVID-19 lockdown hit India's economy. 2020. https://news.cgtn.com/news/2020-06-30/Graphics-How- COVID-19lockdown-hit-India-s-economy-RJSmm5Laes/index.html (August 19, 2020). 